\title{
Multifocal urothelial carcinoma -a case report
}

\author{
DR.C.Aparna, Associate Professor, Dr.I.V.Renuka, professor, Dr.C.Padmavathi Devi \\ Prof\&HOD, Dr.Maruthi devi, Asst prof, Dr.Kishore kumar,P.G. \\ Department of pathology, Guntur medical college, Guntur, Andhra Pradesh.India.
}

\begin{abstract}
The authors have reported a case in a forty year old male patient. It was a multifocal papillary urothelial carcinoma with extravesical extension.

Key words: multifocal, urothelial
\end{abstract}

\section{Introduction:}

Urothelial carcinomas or transitional cell carcinomas comprise approximately $90 \%$ of all primary tumors of bladder. ${ }^{[1]}$ Bladder tumors are more common in industrial areas compounded by exposure to cigarette smoke and aryl amines. Other environmental factors include exposure to benzidine and beta naphthylamine. Urinary tryptophan metabolites may be the endogeneous counterparts of the carcinogenic dyes. Schistosoma haematobium is also thought to be causing urothelial carcinoma.

\section{Case history}

A male patient aged about 40 years came to the urology clinics with complaints of left flank pain and hematuria. He was a farm labourer and smoker since 20 years . ultrasound scan report showed a vesical mass lesion with left gross hydronephrosis and focal mucosal thickening of urinary bladder. We received two containers. One container showed kidney with ureter of length $6 \mathrm{cms}$ and kidney of size $14 \times 7 \times 3.5 \mathrm{cms}$. Cut section showed a papillary and friable tumor of size $2.5 \mathrm{cms}$ in the pelvis. Rest of the ureter showed no tumor. Capsule of the kidney could be stripped of easily . No lymph nodes identified. Perinephric fat appeared normal. (Figure1)

Container 2: Cystoprostatectomy specimen of size $11 \times 6.5 \times 4 \mathrm{cms}$. ureter of length $10.5 \mathrm{cms}$. The bladder wall was thickened (? Prostate.) and it shows a papillary tumor of $2 \times 2 \times 1 \mathrm{cms}$. C/s of lower part of ureter was filled with a papillary tumor. We also received left and right pelvic, para aortic group of lymphnodes. (Figure2)

Microscopy ; pelvis of the kidney showed picture of an invasive urothelial carcinoma.proximal ureter showed no growth. Cortex was un involved.(Figure3)

Cystoprostatectomy specimen showed a urothelial carcinoma infiltrating into inner half of muscularis propria, perivesicular fat, and with vascular invasion. We staged it as T3NOMX. ( Table1)Distal ureter showed a high grade urothelial Carcinoma(fig4).All the lymphnodes showed no deposit.

\section{Discussion}

Simultaneous or metachronous development of multifocal tumors with identical or variable histology in the urothelial tract in a single patient is well known feature of urothelial cancer. To explain this two theories have been proposed. One is the "field cancerization"hypothesis - the urothelial cells are primed to undergotransformation by previous carcinogenic insults. Another hypothesis is the "Single progenitor cell "hypothesis, which asserts that genetic and phenotypic diversity is a consequence of clonal evolution of a single transformed cell. ${ }^{[2]}$ current molecular pathology studies are supporting this concept.

The authors reported a multicentric transitional cell carcinoma in the pelvis, of the kidney, ureter and bladder. StageIII, T3bNoMx. (Table1) This is the first time our institute has witnessed such a radical nephro ureterectomy ,cystoprostatectomy specimen along with pelvic and para aortic group of lymphnodes. We followed WHO classification and TNM staging. Though there is no diagnostic controversy, the case is presented in view of its rarity. 
Table 1:Pathologic T staging of blader carcinoma. ${ }^{(3)}$

\begin{tabular}{|l|l|}
\hline Depth of invasion & AJCC/UICC \\
\hline Ta & $\begin{array}{l}\text { Non } \\
\text { invasive,papillary }\end{array}$ \\
\hline Tis & $\begin{array}{l}\text { Carcinoma in } \\
\text { situ( non invasive } \\
\text { flat) }\end{array}$ \\
\hline T1 & $\begin{array}{l}\text { Lamina propria } \\
\text { invasion }\end{array}$ \\
\hline T2 & $\begin{array}{l}\text { Muscularis } \\
\text { propria invasion }\end{array}$ \\
\hline T3a & $\begin{array}{l}\text { Microscopic } \\
\text { extra vesical } \\
\text { invasion }\end{array}$ \\
\hline T3b & $\begin{array}{l}\text { Grossly apparent } \\
\text { extravesical } \\
\text { invasion }\end{array}$ \\
\hline T4 & $\begin{array}{l}\text { Invades adjacent } \\
\text { structures }\end{array}$ \\
\hline
\end{tabular}

\section{References}

[1]. Rosai, Ackerman. Urinary tract .In:Nelson G. Ordonez, Juan Rosai: Rosai and Ackerman's surgical pathology, 10 ${ }^{\text {th, }}$ ed , st. Louis;Mosby: 2011:1257-1265.

[2]. Tomonari Habuchi. International journal of urology 2005;12:709-716.

[3]. A.Lopez-Beltran etal.,in :pathology and genetics of tumors of the urinary system and male genital organs. WHO classification of tumors, John N.Eble,GuidoSauter, Jonathan I.Epstein,IsabellA.Sesterhenn(ed), lyon;2004:90.

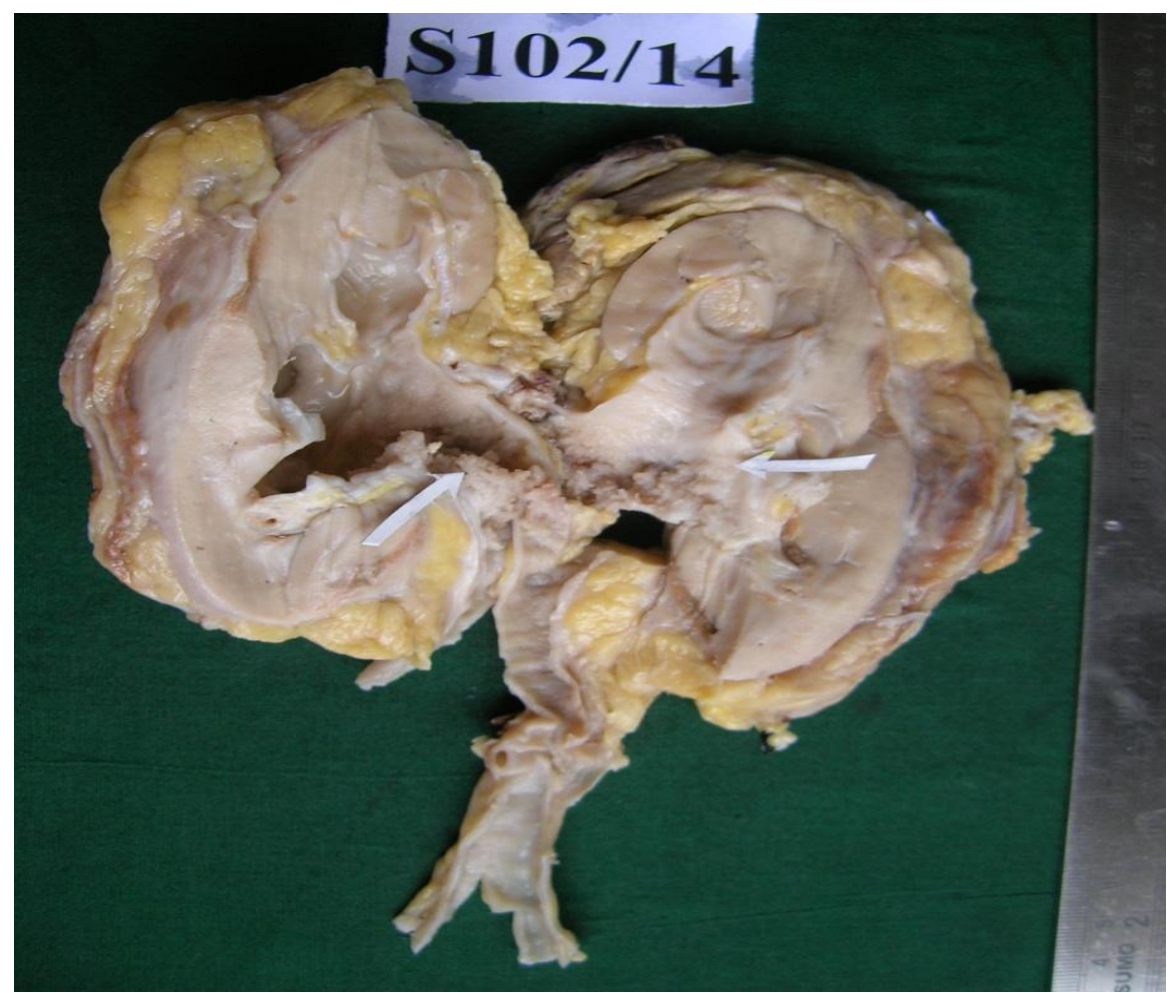

Fig 1. Gross specimen of kidney with ureter showing growth in the pelvis. 


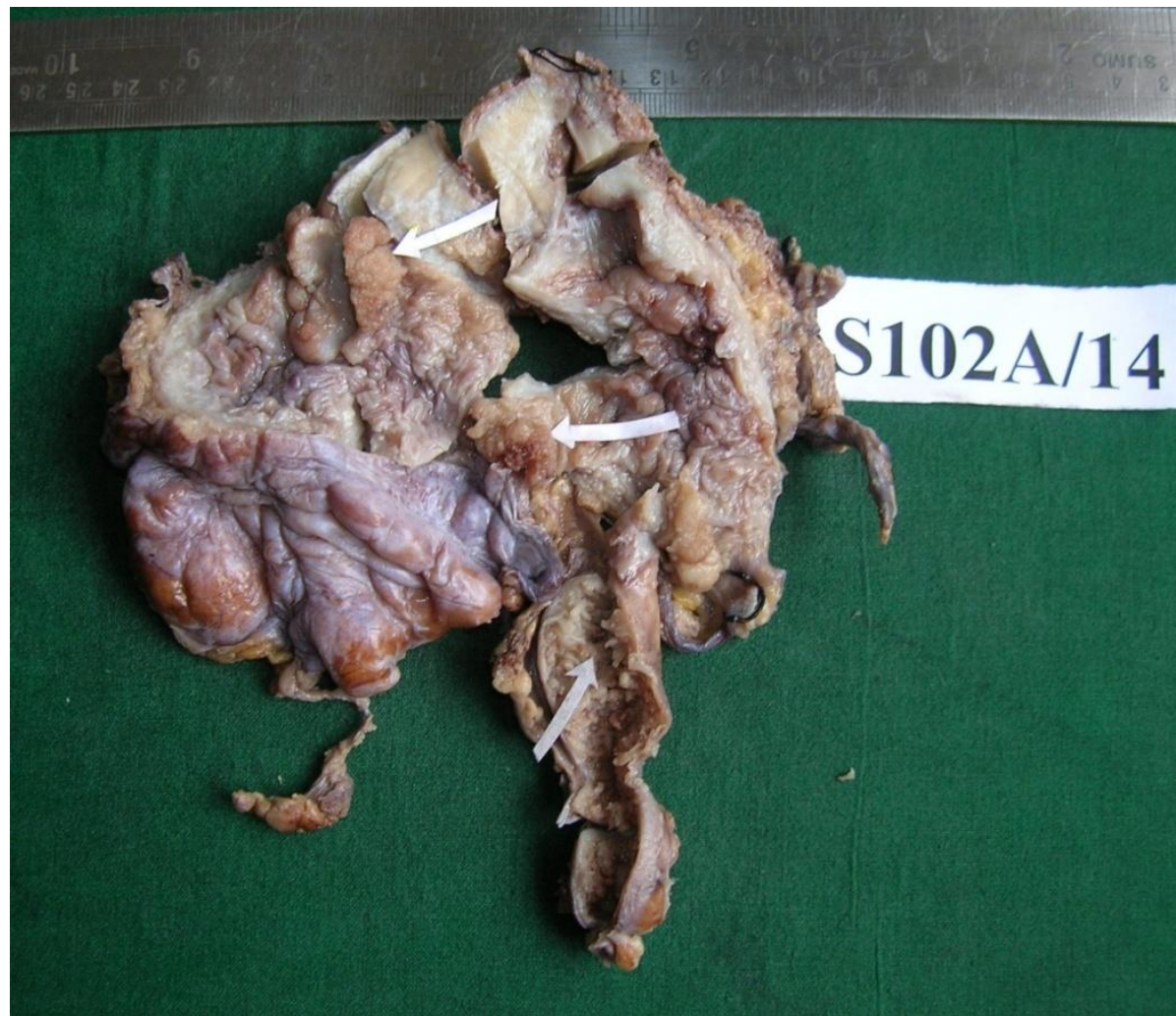

Fig2 . cystoprostatectomy specimen with ureter showing growth both in the bladder and lower end of ureter.

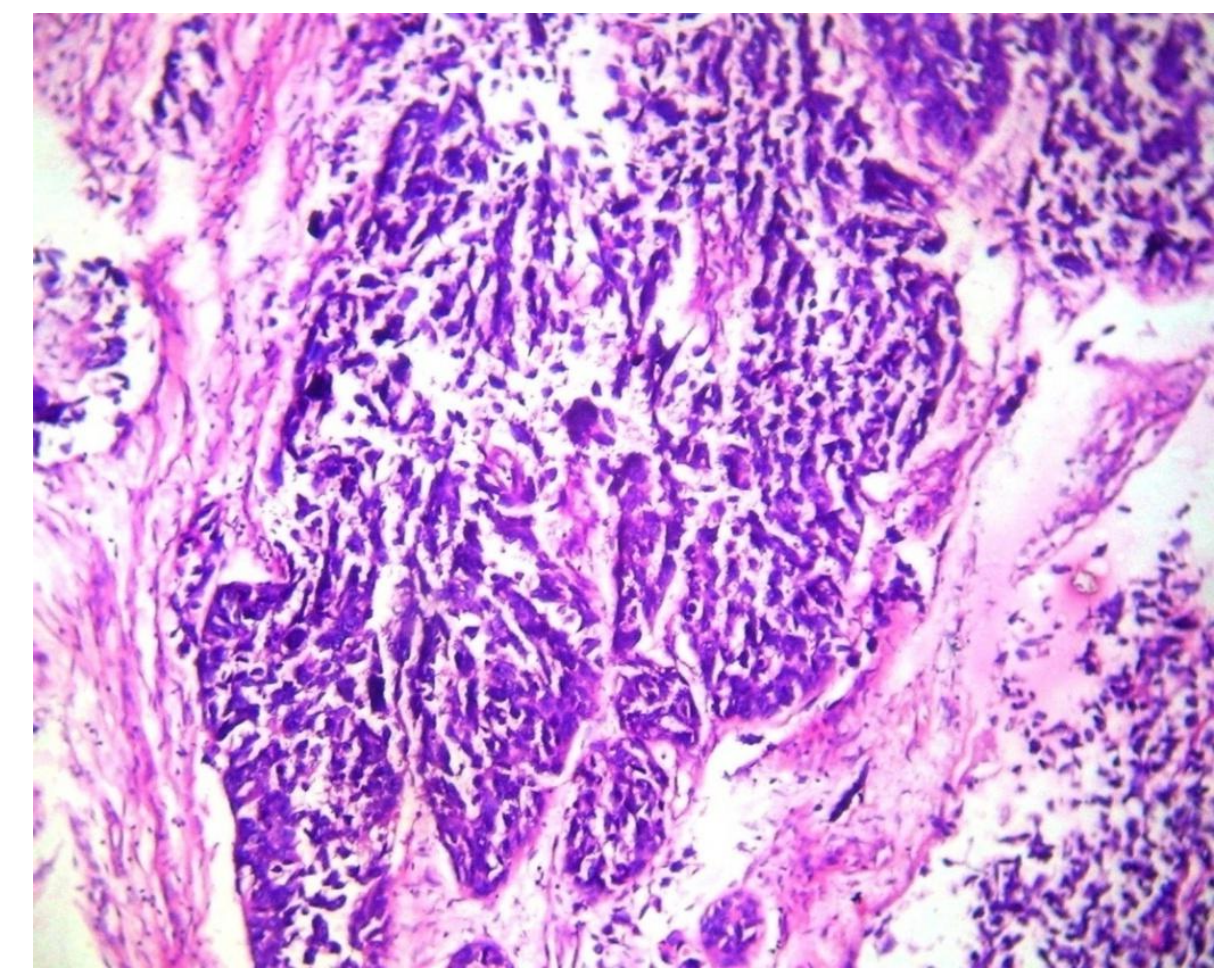

Fig3. Microscopic picture of Urothelial carcinoma of renal pelvis.H\&E10x40 


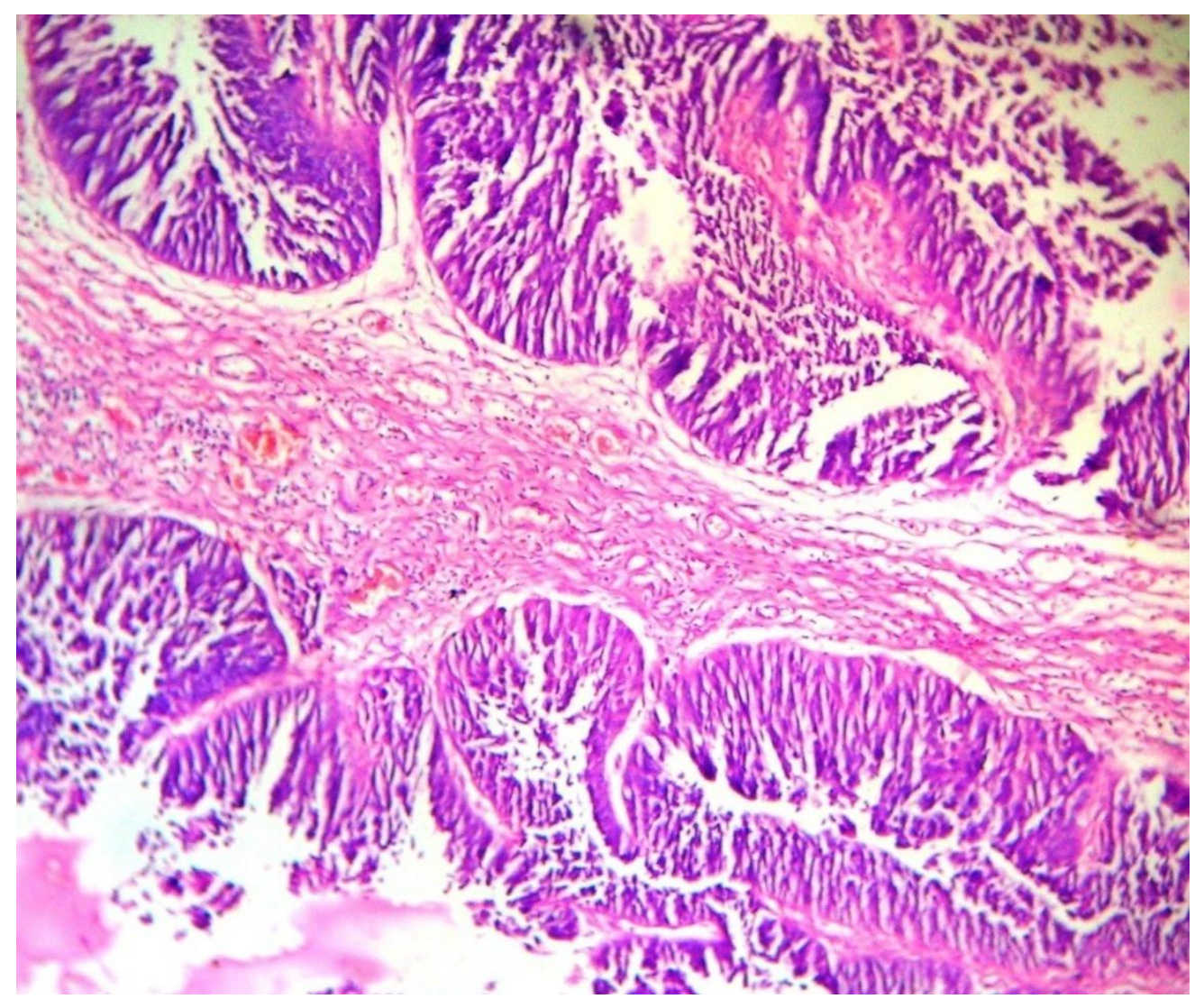

Fig4. Microscopic picture of Urothelial carcinoma in bladder.H\&E10x40 